\title{
Landmarks in Our Understanding of Insulin Synthesis Secretion and Action
}

\author{
Krishna G. Seshadri'1,2 \\ ${ }^{1}$ Apollo Sugar Apollo Hospitals Chennai, Chennai, India \\ ${ }^{2}$ Diabetes and Endocrine Clinic, Chennai, India \\ Email: krishnagseshadri@gmail.com
}

How to cite this paper: Seshadri, K.G. (2021) Landmarks in Our Understanding of Insulin Synthesis Secretion and Action. Journal of Diabetes Mellitus, 11, 191-199. https://doi.org/10.4236/jdm.2021.115016

Received: September 29, 2021

Accepted: November 13, 2021

Published: November 16, 2021

Copyright (c) 2021 by author(s) and Scientific Research Publishing Inc. This work is licensed under the Creative Commons Attribution International License (CC BY 4.0).

http://creativecommons.org/licenses/by/4.0/

\begin{abstract}
The discovery and the use of insulin to treat patients in January 1922 marked an important milestone in our quest for finding out the cause and cure for diabetes-a disease haunting humanity since ancient times. The pace of discovery accelerated since the discovery of the islets of langerhans. This review focuses on the advances since 1922 that have helped us understand the nature control secretion function and action of insulin. From its physical characterization in the mid-1920s to determination of its molecular structure, precursor and measurement in the 1950s through the discovery of its receptor tyrosine phosphorylation and gene in the eighties these advances have borrowed from and contributed richly to advances in protein genetics and molecular biology. Paralleling advances in purification modification and delivery of insulin, these advances form the basis of our understanding and the therapy of diabetes.
\end{abstract}

\section{Keywords}

Insulin, Discovery, Synthesis, Physicochemical Characterization, Proinsulin, Incretin, Tyrosine Kinase, KNCJ11, SNARE Complex

\section{Introduction}

Diabetes was known in the ancient world. Sushrusha had even classified it into two different kinds whose features are comparable to what we recognize as Type 1 and Type 2 diabetes. The Eber's papyrus documented a remedy used to treat diabetes in ancient Egypt [1].

The treatment of the child Leonard Thomson with a purified pancreatic extract on January 231922 was a culmination of work that began in the nineteenth century that led to the identification and clinical use of insulin. There are indeed 
other claimants to the discovery of insulin; the Toronto four were the first to use it to save lives [2]. There are excellent reviews on the events that lead to the discovery of insulin. We will confine ourselves to landmarks that helped us understand the secretion and action of insulin since 1922 [1]. We will not also address the advances in insulin production, commercialization, modification and manufacture that are again well reviewed [3]. The review is not meant to be an exhaustive review of the many contributions that have shaped the science; it is intended to record the key events that have helped us understand insulin, its biology and action (Figure 1).

\section{Characterization of Insulin}

In 1925 John Abel at Johns Hopkins was able to crystallize insulin. Abel had other laurels to his credit including the isolation of adrenaline [4]. Working in John Abel's lab Vincent Du Vigneaud identified disulfide linked cysteine in insulin [5]. He also recognized that up to $30 \%$ of the insulin molecule was made up of cystine, tyrosine, arginine, histidine and lysine and speculated that the rest of the molecule was also made up of amino acids [6]. Du Vigenaud incidentally won the Nobel Prize in chemistry (1955) for the discovery of oxytocin. Despite this it was widely considered that insulin acted through a smaller molecule like thyroxine or adrenaline. Working in Abel's lab it was Hans Jensen and Earl A Evans Jr who established that the material isolated by acid extraction was indeed a protein. They also identified for the first time an $\mathrm{N}$ terminal phenylalanine end group [7]. Insulin secretion from isolated human islet cells was demonstrated in $1976[8]$

\section{Sequencing and Assay}

Frederik Sanger was working with protein chemistry; his attention turned to insulin simply because of its easy availability with reasonable purity. Sanger helped determine that insulin had two chains and he also sequenced both chains [9]. Insulin indeed was the first protein that was sequenced and resulted in one of the two Nobel prizes that Sanger received. The determination of the three dimensional structure of insulin was through a 34 year old effort of Dorothy Hodgkins. Her group first published an electronic density map of the structure of porcine zinc. [10] Insulin was the first protein to be synthesized. It was also the first hormone to be assayed. This was the work of Berson and Yalow who reported an immunoassay for plasma insulin based on the reaction of human insulin competing with beef I131 insulin in the sera of guinea pigs immunized with beef insulin [11].

\section{Synthesis of Insulin}

Based on work done initially on an islet cell adenoma (insulinoma), Donald Steiner and his colleagues working in the University of Chicago reported the discovery of the precursor of insulin in 1968 which they named proinsulin [12]. 


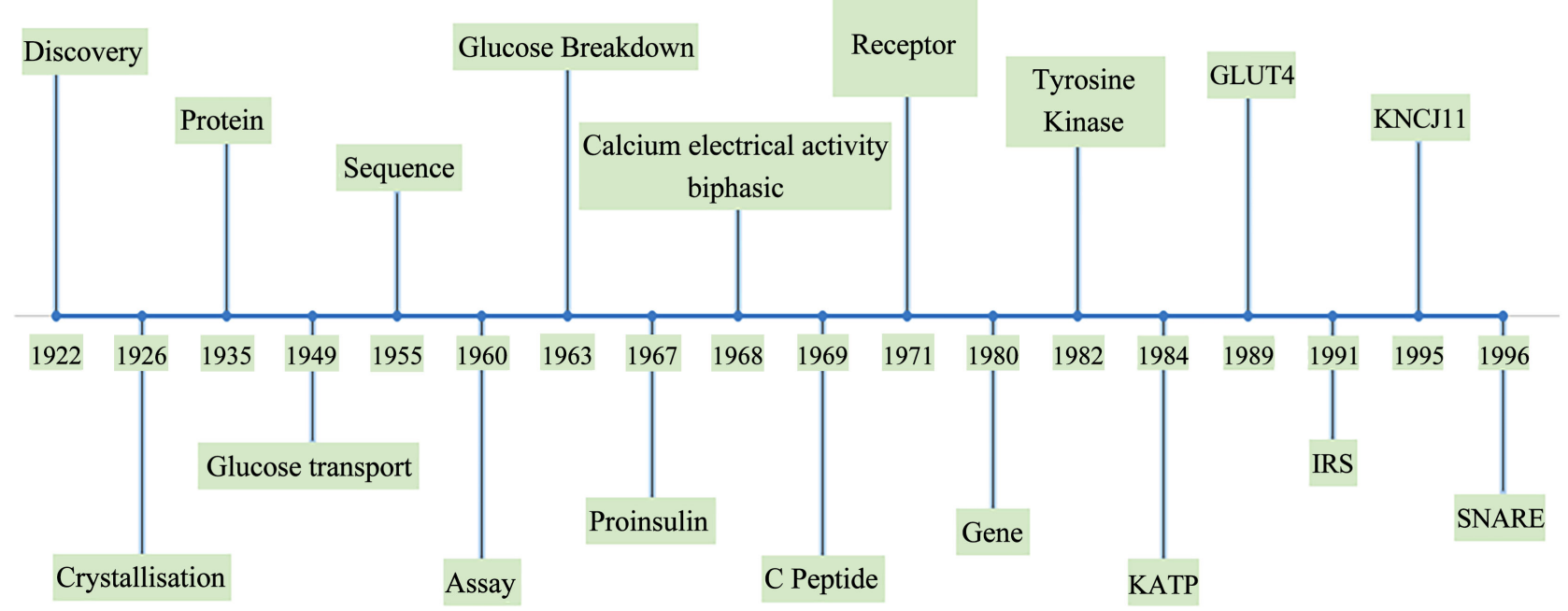

Figure 1. Landmarks in our understanding of insulin its secretion and action (see text for expansion of abbreviations and details).

Through pulse chase techniques they subsequently demonstrate the time lapse in accumulation of proinsulin and its conversion of insulin [13]. This led to the development of models predicting that newly synthesized proinsulin moved from the endoplasmic reticulum (ER) to the Golgi region within 15 - 20 min, a process requiring energy, and shortly thereafter was packaged into secretory granules and then converted to insulin. This was subsequently confirmed by Leilo Orci and colleagues in 1985 [14]. Steiner and his colleagues further identified connecting peptide (c-peptide) and also demonstrated that it was stored in mature granules and secreted along with insulin [15]. This was used to develop a C-peptide assay as an index of beta cell function by Arthur Rubenstein and Kenneth Polonsky.

\section{Gene}

It is commonly assumed that the human insulin gene was cloned and then introduced into E. coli to make the first recombinant Human Insulin that was introduced in 1981. Neither the mRNA nor the gene sequence of insulin was known. The genes were designed based on the known amino acid sequences and the codons preferred by $E$. coli. The genes were then chemically synthesized by organic chemical methods. It was sheer providence that $E$. coli synthesized human insulin [16] [17]. Subsequently David Owerbach, Graeme Bell and colleagues described the location of human insulin in short of chromosome 11 in 1980 [18] [19].

\section{Control of Insulin Secretion}

Work on stimulus secretion coupling that was started in the 1960s resulted in three seminal discoveries [20]. The first was that the insulin secretion required the metabolic breakdown of glucose [21] [22]. Thirty years later glucokinase was identified as the first glucose metabolizing enzyme [23]. The role of amino acids 
in insulin secretion was also first understood around this time with the identification of the insulinotropic effects of leucine [24]. Demonstration of the effects of amino and keto acids further strengthened the view that the mitochondrial matrix is the hub of nutrient control of insulin synthesis [25]. Of note the differential effects of intravenous and oral glucose on insulin dynamics-the incretin effect was described by Perley et al. in 1967 [26].

The second was the discovery that glucose does not increase insulin signaling in the absence of calcium. Grodsky and Bennet (1966) demonstrated that calcium was necessary for the pancreas to secrete insulin [27]. Subsequently Milner and Hales (1967) demonstrated that a sodium pump was involved in insulin secretion. They also demonstrated that increase in extracellular potassium stimulated insulin secretion. Interestingly they demonstrated that the sulfonylurea tolbutamide increased insulin secretion independent of glucose concentration [28].

The third was the discovery that pancreatic beta cells are electrically excitable which was accomplished by recording the action potential [29]. A decrease in glucose induced potassium efflux as the triggering event for electrical activity of the beta cell was postulated in 1978 [30]. The demonstration that mitochondrial activation through increased oxidative phosphorylation and alteration in the ATP/ADP ratio results in electrical activation of the beta cell and the identification of the KATP channel by Cook and colleagues in 1984 provided a link between nutrient stimulus and electrical activity [31]. Its molecular compositionan inwardly rectifying $\mathrm{K}+$ channel (Kir $6.2=\mathrm{KCNJ} 11$ ) as the pore-forming unit and a member of the ATP cassette-binding family (SUR1 = ABCC8) as the regulatory subunit was described in 1995 [32].

\section{Mechanics of Insulin Secretion}

The involvement of a cytoskeleton in the transport of synthesized insulin was proposed as early as 1968 [33]. These were confirmed by work done in the 70s [34]. Grodsky and colleagues demonstrated biphasic insulin secretion perfused pancreas in 1968 [27]. The availability of new techniques helped understand the segregation of insulin granules to different pools. The role of secretory machinery such as the SNARE complex were first identified in the 90s [35]. Work on refining our understanding of the secretory dynamics has continued well into the 21 st century.

\section{Insulin Action}

That insulin exerted its action by transport of glucose across cell membranes in extrahepatic tissues was postulated by Rachmiel Levene in 1949 [36]. In 1960 glycogen synthase was identified as the first enzyme to be stimulated by insulin. The existence of a membrane receptor for insulin was first demonstrated by Jesse Roth and colleagues [37]. Working with patients with severe insulin resistance (type B) characterised by antibodies to the insulin receptor Ronald C Kahn 
and his colleagues were able to identify tyrosine kinase activity and identify that the insulin receptor belonged to the tyrosine kinase family [38] [39]. That the receptor becomes phosphorylated on tyrosine residues in response to insulin binding was an unexpected finding, as tyrosine phosphorylation had until then been thought of as exclusive to oncogenes. This recognition was undoubtedly a major landmark in the understanding of insulin and its action and shifted the focus from the cell surface to intracellular pathways. This concept was strengthened by the cloning of the insulin receptor cDNA by two groups in 1985 [40].

Evidence for an intracellular transport mechanism for glucose came with the discovery by Tetsuro Kono and colleagues from Vanderbilt and Samuel Cushman and colleagues from the NIH that insulin promoted the translocation of a cellular transporter of glucose to the surface in insulin sensitive tissue [41] [42]. This transporter was further characterized, cloned and named-GLUT4 in 1989 [43]. The first of four insulin receptor substrate proteins were cloned by Kahn and White in 1991 [44]. These adaptor proteins were identified as responsible to convert the tyrosine phosphorylase signal into a lipid kinase signal by recruitment of PI3K [40]. Further understanding the distal actions of insulin signaling was accomplished by the identification of AKT as an insulin activated serine threonine Tyrosine Kinase signal by Kohn et al in 1995 [45]. Continued work on our understanding of insulin action has proceeded well into the 21st century

\section{Miscellaneous}

There are several other streams of work that have helped us further understand insulin and its secretion and action in health and disease. For instance neuronal control of insulin secretion was first proposed by Claude Bernard who demonstrated glucosuria by puncture of the floor of the fourth ventricle [1]. Work on glucagon by Roger Unger and colleagues' merits mention [46]. While the work on insulin has helped us understand other hormonal action, work on hormones such as somatostatin has been a forerunner for quite a volume of work on insulin.

Work on genetic conditions that influence insulin secretion and action have helped us understand insulin (and diabetes) better-an example is the discovery of the inheritance and characterization of Maturity Onset Diabetes in the Young [47]. An association between inflammation and diabetes was demonstrated as early as 1876. High doses of sodium salicylate were used to treat diabetes [48]. The relationship between inflammation insulin resistance and insulin secretion and action are areas of active interest at this time.

Advances in cellular and molecular biology that began with the pioneering work of Watson and Crick [49], techniques to interrogate single cells, the glucose clamp [50], and ability to directly image beta cells are but a few examples of the considerable impact of advances in the last century on the science of insulin. This article has not done justice to these contributions. Mention must be made of the tremendous advances in our ability to study insulin biology in animal 
models (such as knock out or humanized mice) and cells (in vitro) in the past century. These require a tribute of their own. Lastly it must be emphasized that the contribution of patients with rare genetic syndromes and complex problems to the science and biology of insulin has been priceless

\section{Conclusion}

We know far more about the heaps of cells that were first identified by Paul Langerhans [1]. The scientists who have spent a lifetime in the pursuit of the biology of insulin have helped us understand not only the working of the endocrine system but also pursue therapies for diabetes. In retrospect the achievements of the last century are indeed a testimony to human quest for truth and perseverance. These achievements also epitomize in many ways the power of collaboration networks and mentorship.

\section{Conflicts of Interest}

The author declares no conflicts of interest regarding the publication of this paper.

\section{References}

[1] Rostène, W. and De Meyts, P. (2021) Insulin: A Hundred Year-Old Discovery with a Fascinating History. Endocrine Reviews, 42, 503-527.

https://doi.org/10.1210/endrev/bnab020

[2] Banting, F.G., Best, C.H., Collip, J.B., Campbell, W.R. and Fletcher, A.A. (1922) Pancreatic Extracts in the Treatment of Diabetes Mellitus. The Canadian Medical Association Journal, 12, 141-146.

[3] Hirsch, I.B., Juneja, R., Beals, J.M., Antalis, C.J. and Wright, E.E. (2020) The Evolution of Insulin and How It Informs Therapy and Treatment Choices. Endocrine Reviews, 41, 733-755. https://doi.org/10.1210/endrev/bnaa015

[4] Abel, J.J. (1926) Crystalline Insulin. Proceedings of the National Academy of Sciences of the United States of America, 12, 132-136. https://doi.org/10.1073/pnas.12.2.132

[5] du Vigneaud, V. (1927) The Sulfur of Insulin. Journal of Biological Chemistry, 75, 393-405. https://doi.org/10.1016/S0021-9258(18)84151-5

[6] Du Vigneaud, V., Jensen, H. and Wintersteiner, O. (1928) Studies on Crystalline Insulin III. Further Observations on the Crystallization of Insulin and on the Nature of the Sulfur Linkage. The Isolation of Cystine and Tyrosine from Hydrolyzed Crystalline Insulin. Journal of Pharmacology and Experimental Therapeutics, 32, 367-385.

[7] Jensen, H. and Evans, E.A. (1935) Studies on Crystalline Insulin: XVIII. The Nature of the Free Amino Groups in Insulin and the Isolation of Phenylalanine and Proline from Crystalline Insulin. Journal of Biological Chemistry, 108, 1-9. https://doi.org/10.1016/S0021-9258(18)75301-5

[8] Andersson, A., Borg, H., Groth, C.G., Gunnarsson, R., Hellerström, C., Lundgren, G., et al. (1976) Survival of Isolated Human Islets of Langerhans Maintained in Tissue Culture. Journal of Clinical Investigation, 57, 1295-1301. https://doi.org/10.1172/JCI108397

[9] Brown, H., Sanger, F. and Kitai, R. (1955) The Structure of Pig and Sheep Insulins. Biochemical Journal, 60, 556-565. https://doi.org/10.1042/bj0600556 
[10] Blundell, T.L., Cutfield, J.F., Dodson, E.J., Dodson, G.G., Hodgkin, D.C. and Mercola, D.A. (1972) The Crystal Structure of Rhombohedral 2 Zinc Insulin. Cold Spring Harbor Symposia on Quantitative Biology, 36, 233-241. https://doi.org/10.1101/SQB.1972.036.01.031

[11] Yalow, R.S. and Berson, S.A. (1960) Immunoassay of Endogenous Plasma Insulin in Man. Journal of Clinical Investigation, 39, 1157-1175. https://doi.org/10.1172/JCI104130

[12] Steiner, D.F. and Oyer, P.E. (1967) The Biosynthesis of Insulin and a Probable Precursor of Insulin by a Human Islet Cell Adenoma. Proceedings of the National Academy of Sciences of the United States of America, 57, 473-480. https://doi.org/10.1073/pnas.57.2.473

[13] Steiner, D.F., Cunningham, D., Spigelman, L. and Aten, B. (1967) Insulin Biosynthesis: Evidence for a Precursor. Science, 157, 697-700.

https://doi.org/10.1126/science.157.3789.697

[14] Orci, L., Ravazzola, M., Amherdt, M., Madsen, O., Vassalli, J.D. and Perrelet, A. (1985) Direct Identification of Prohormone Conversion Site in Insulin-Secreting Cells. Cell, 42, 671-681. https://doi.org/10.1016/0092-8674(85)90124-2

[15] Clark, J.L. and Steiner, D.F. (1969) Insulin Biosynthesis in the Rat: Demonstration of Two Proinsulins. Proceedings of the National Academy of Sciences of the United States of America, 62, 278-285. https://doi.org/10.1073/pnas.62.1.278

[16] Crea, R., Kraszewski, A., Hirose, T. and Itakura, K. (1978) Chemical Synthesis of Genes for Human Insulin. Proceedings of the National Academy of Sciences of the United States of America, 75, 5765-5769. https://doi.org/10.1073/pnas.75.12.5765

[17] Riggs, A.D. (2021) Making, Cloning, and the Expression of Human Insulin Genes in Bacteria: The Path to Humulin. Endocrine Reviews, 42, 374-380. https://doi.org/10.1210/endrev/bnaa029

[18] Owerbach, D., Bell, G.I., Rutter, W.J. and Shows, T.B. (1980) The Insulin Gene Is Located on Chromosome 11 in Humans. Nature, 286, 82-84.

https://doi.org/10.1038/286082a0

[19] Owerbach, D., Bell, G.I., Rutter, W.J., Brown, J.A. and Shows, T.B. (1981) The Insulin Gene Is Located on the Short Arm of Chromosome 11 in Humans. Diabetes, 30, 267-270. https://doi.org/10.2337/diab.30.3.267

[20] Henquin, J.C. (2000) Triggering and Amplifying Pathways of Regulation of Insulin Secretion by Glucose. Diabetes, 49, 1751-1760.

https://doi.org/10.2337/diabetes.49.11.1751

[21] Grodsky, G.M., Batts, A.A., Bennett, L.L., Vcella, C., Mcwilliams, N.B. and Smith, D.F. (1963) Effects of Carbohydrates on Secretion of Insulin from Isolated Rat Pancreas. American Journal of Physiology, 205, 638-644.

https://doi.org/10.1152/ajplegacy.1963.205.4.638

[22] Coore, H.G. and Randle, P.J. (1964) Regulation of Insulin Secretion Studied with Pieces of Rabbit Pancreas Incubated in Vitro. Biochemical Journal, 93, 66-78. https://doi.org/10.1042/bj0930066

[23] Randle, P.J. (1993) Glucokinase and Candidate Genes for Type 2 (Non-Insulin-Dependent) Diabetes Mellitus. Diabetologia, 36, 269-275.

https://doi.org/10.1007/BF00400227

[24] Sener, A. and Malaisse, W.J. (1980) L-Leucine and a Nonmetabolized Analogue Activate Pancreatic Islet Glutamate Dehydrogenase. Nature, 288, 187-189.

https://doi.org/10.1038/288187a0 
[25] Rustenbeck, I., Schulze, T., Morsi, M., Alshafei, M. and Panten, U. (2021) What Is the Metabolic Amplification of Insulin Secretion and Is It (Still) Relevant? Metabolites, 11, 355. https://doi.org/10.3390/metabo11060355

[26] Perley, M.J. and Kipnis, D.M. (1967) Plasma Insulin Responses to Oral and Intravenous Glucose: Studies in Normal and Diabetic Subjects. Journal of Clinical Investigation, 46, 1954-1962. https://doi.org/10.1172/JCI105685

[27] Curry, D.L., Bennett, L.L. and Grodsky, G.M. (1968) Dynamics of Insulin Secretion by the Perfused Rat Pancreas. Endocrinology, 83, 572-584. https://doi.org/10.1210/endo-83-3-572

[28] Hales, C.N. and Milner, R.D. (1968) The Role of Sodium and Potassium in Insulin Secretion from Rabbit Pancreas. The Journal of Physiology, 194, 725-743. https://doi.org/10.1113/jphysiol.1968.sp008433

[29] Dean, P.M. and Matthews, E.K. (1968) Electrical Activity in Pancreatic Islet Cells. Nature, 219, 389-390. https://doi.org/10.1038/219389a0

[30] Henquin, J.C. (1978) D-Glucose Inhibits Potassium Efflux from Pancreatic Islet Cells. Nature, 271, 271-273. https://doi.org/10.1038/271271a0

[31] Cook, D.L. and Hales, C.N. (1984) Intracellular ATP Directly Blocks K+ Channels in Pancreatic B-Cells. Nature, 311, 271-273. https://doi.org/10.1038/311271a0

[32] Inagaki, N., Gonoi, T., Clement, J.P., Namba, N., Inazawa, J., Gonzalez, G., et al. (1995) Reconstitution of IKATP: An Inward Rectifier Subunit plus the Sulfonylurea Receptor. Science, 270, 1166-1170. https://doi.org/10.1126/science.270.5239.1166

[33] Lacy, P.E., Howell, S.L., Young, D.A. and Fink, C.J. (1968) New Hypothesis of Insulin Secretion. Nature, 219, 1177-1179. https://doi.org/10.1038/2191177a0

[34] Malaisse-Lagae, F., Amherdt, M., Ravazzola, M., Sener, A., Hutton, J.C., Orci, L., et al. (1979) Role of Microtubules in the Synthesis, Conversion, and Release of (Pro)insulin. A Biochemical and Radioautographic Study in Rat Islets. Journal of Clinical Investigation, 63, 1284-1296. https://doi.org/10.1172/JCI109423

[35] Nagamatsu, S., Fujiwara, T., Nakamichi, Y., Watanabe, T., Katahira, H., Sawa, H., et al. (1996) Expression and Functional Role of Syntaxin 1/HPC-1 in Pancreatic Beta Cells. Syntaxin 1A, But Not 1B, Plays a Negative Role in Regulatory Insulin Release Pathway. Journal of Biological Chemistry, 271, 1160-1165.

https://doi.org/10.1074/jbc.271.2.1160

[36] Levine, R., Simkin, B. and Cunningham, W. (1949) Insulin Sensitivity of the Extrahepatic Tissues of the Adrenalectomized Rat. American Journal of Physiology, 159, 111-117. https://doi.org/10.1152/ajplegacy.1949.159.1.111

[37] Freychet, P., Roth, J. and Neville, D.M. (1971) Insulin Receptors in the Liver: Specific Binding of (125 I)insulin to the Plasma Membrane and Its Relation to Insulin Bioactivity. Proceedings of the National Academy of Sciences of the United States of America, 68, 1833-1837. https://doi.org/10.1073/pnas.68.8.1833

[38] Kasuga, M., Karlsson, F.A. and Kahn, C.R. (1982) Insulin Stimulates the Phosphorylation of the 95,000-Dalton Subunit of Its Own Receptor. Science, 215, 185-187. https://doi.org/10.1126/science.7031900

[39] Neill, U.S. (2020) A Conversation with C. Ronald Kahn. Journal of Clinical Investigation, 130, 5029-5030. https://doi.org/10.1172/JCI143687

[40] Haeusler, R.A., McGraw, T.E. and Accili, D. (2018) Biochemical and Cellular Properties of Insulin Receptor Signalling. Nature Reviews Molecular Cell Biology, 19, 31-44. https://doi.org/10.1038/nrm.2017.89

[41] Suzuki, K. and Kono, T. (1980) Evidence that Insulin Causes Translocation of Glu- 
cose Transport Activity to the Plasma Membrane from an Intracellular Storage Site. Proceedings of the National Academy of Sciences of the United States of America, 77, 2542-2545. https://doi.org/10.1073/pnas.77.5.2542

[42] Cushman, S.W. and Wardzala, L.J. (1980) Potential Mechanism of Insulin Action on Glucose Transport in the Isolated Rat Adipose Cell. Apparent Translocation of Intracellular Transport Systems to the Plasma Membrane. Journal of Biological Chemistry, 255, 4758-4762. https://doi.org/10.1016/S0021-9258(19)85561-8

[43] James, D.E., Strube, M. and Mueckler, M. (1989) Molecular Cloning and Characterization of an Insulin-Regulatable Glucose Transporter. Nature, 338, 83-87. https://doi.org/10.1038/338083a0

[44] Sun, X.J., Rothenberg, P., Kahn, C.R., Backer, J.M., Araki, E., Wilden, P.A., et al. (1991) Structure of the Insulin Receptor Substrate IRS-1 Defines a Unique Signal Transduction Protein. Nature, 352, 73-77. https://doi.org/10.1038/352073a0

[45] Kohn, A.D., Kovacina, K.S. and Roth, R.A. (1995) Insulin Stimulates the Kinase Activity of RAC-PK, a Pleckstrin Homology Domain Containing ser/thr Kinase. EMBO Journal, 14, 4288-4295. https://doi.org/10.1002/j.1460-2075.1995.tb00103.x

[46] Unger, R.H. and Orci, L. (1975) The Essential Role of Glucagon in the Pathogenesis of Diabetes Mellitus. The Lancet, 1, 14-16. https://doi.org/10.1016/S0140-6736(75)92375-2

[47] Tattersall, R.B. and Fajans, S.S. (1975) A Difference between the Inheritance of Classical Juvenile-Onset and Maturity-Onset Type Diabetes of Young People. Diabetes, 24, 44-53. https://doi.org/10.2337/diab.24.1.44

[48] Shoelson, S.E., Lee, J. and Goldfine, A.B. (2006) Inflammation and Insulin Resistance. Journal of Clinical Investigation, 116, 1793-1801.

https://doi.org/10.1172/JCI29069

[49] Watson, J.D. and Crick, F.H. (1953) Molecular Structure of Nucleic Acids, a Structure for Deoxyribose Nucleic Acid. Nature, 171, 737-738. https://doi.org/10.1038/171737a0

[50] DeFronzo, R.A., Tobin, J.D. and Andres, R. (1979) Glucose Clamp Technique: A Method for Quantifying Insulin Secretion and Resistance. American Journal of Physiology, 237, E214-E223. https://doi.org/10.1152/ajpendo.1979.237.3.E214 